Article

\title{
Limitations of Rural Tourism as an Economic Diversification and Regional Development Instrument. The Case Study of the Region of La Vera
}

\author{
Francisco Javier Castellano-Álvarez ${ }^{1}$ (i) , María de la Cruz del Río-Rama ${ }^{2}$ (D), \\ José Álvarez-García ${ }^{3, *(D)}$ and Amador Durán-Sánchez ${ }^{3}$ (D) \\ 1 Economy Department, Faculty of Business, Finance and Tourism, University of Extremadura, \\ 10071 Cáceres, Spain; fcocastellano@unex.es \\ 2 Business Organisation and Marketing Department, Faculty of Business Administration and Tourism, \\ University of Vigo, 32004 Ourense, Spain; delrio@uvigo.es \\ 3 Financial Economy and Accounting Department, Faculty of Business, Finance and Tourism, \\ University of Extremadura, 10071 Cáceres, Spain; amduransan@unex.es \\ * Correspondence: pepealvarez@unex.es; Tel.: +34-927257968
}

Received: 31 May 2019; Accepted: 12 June 2019; Published: 15 June 2019

\begin{abstract}
In the mid-1980s, at the same time as the Common Agricultural Policy (CAP) reforms resulted in a decrease in agricultural employment, the Single European Act transformed the reduction of regional differences into an objective of European regional policy. The LEADER Initiative and the PRODER Program were two of the instruments chosen by the European Commission to deal with the effects that these new challenges would have for the rural environment. This research studies the scope and limitations of these programs. For this, we analyzed their implementation, resorting to the case study of the region of La Vera, Extremadura (Spain). The results show that although the structure of these programs is consistent with the purpose of developing and diversifying rural economies, their application must overcome a number of risks, including an excessive concentration of investments in the tourism sector, which stands out from the rest. In addition to highlighting the limitations of tourism as an axis of development, this research detects some aspects that should be taken into account when implementing these programs.
\end{abstract}

Keywords: rural tourism; economic diversification; PRODER program; LEADER initiative

\section{Introduction}

In the mid-1980s, in a context characterized by the emergence of a new regional policy and the need to address profound reforms of the Common Agricultural Policy (CAP), rural development policies were the response of the European Commission to the foreseeable exclusion of agricultural assets from its sector of activity. To prevent emigration of the rural population, it was necessary to create jobs in sectors other than agriculture. The purpose of the LEADER initiative (a French acronym that means Links between Actions for the Development of the Rural Economy) was to accomplish this. This can also be said of programs like PRODER (Operative Rural Development Program), which were inspired by LEADER, partaking in its purposes and characteristics. This research focuses on analyzing these types of programs.

LEADER and PRODER should not be understood as large investment programs, but rather as initiatives whose main objective is to have a demonstrative character regarding the viability of small local investments. At the end of their program periods, both initiatives were subject to official evaluations. Undoubtedly, these documents are an important source of information, although they usually focus on the analysis of financial execution, or on the calculation of various ratios of a purely 
quantitative nature. This bias gives rise to criticism by authors such as Navarro, Cejudo, and Maroto, whose considerations about official evaluations are that "they do not sufficiently take into account the impacts that these programs generate on the territory" [1] (p. 349).

The academic world finds a broad field of study in the analysis of these impacts from very different perspectives. If the issue is about reviewing some of the most relevant contributions to this area, it is first necessary to refer to those studies that analyze the application of rural development programs in Extremadura (i.e., the region where La Vera is located). Based on a multivariate analysis, the aim of Nieto and Gurría [2] was to explain the rural structure of Extremadura and the impact of these programs. Nieto and Cárdenas analyzed the same issue with a similar methodology in different program periods [3-6], or the distribution of tourism investments among the Extremadura districts $[7,8]$. In any case, in order to incorporate the results achieved by rural development programs into factor analyses, all these investigations take the official evaluations performed as their source of information. Therefore, these analyses may provide different interpretations of the data, but do not manage to transcend them, as the bias of the official evaluations is not overcome; quite the contrary-they become the basis of the analysis. Starting from this handicap, other authors [9] designed an index to evaluate the effectiveness with which the LEADER II initiative is applied in the field of rural tourism in the region of Andalusia.

From a sociological perspective, Garrido and Moyano [10] developed several indicators in order to measure the social capital of the rural areas of Andalusia to implement this type of program. Ramos and Garrido [11] analyzed the relevance of collective action and the influence of the territorial approach on the differentiation of rural spaces. Based on the cases of Wales and Andalusia, Navarro, Woods, and Cejudo [12] evaluated the real involvement of the population in rural development processes. Cejudo, Navarro, and Camacho [13] analyzed the profile and characteristics of promoters of rural development programs in Andalusia, paying special attention to how women and young people benefit from them. The investigations by Muresan et al. [14] are worth mentioning, regarding their application to the field of rural tourism and the use of the case study methodology. By taking a region with great natural and tourist resources as reference, their aim was to evaluate residents' perception towards the development of rural tourism. On the other hand, Quaranta, Citro, and Salvia [15] studied the relevance that the implication of social capital can have for the incorporation of innovations in the rural tourism sector.

The approach of this research lies between purely quantitative and strictly qualitative. This is its main novelty differentiating it from the majority of studies based on financial indicators or from others focused on intangible aspects with a sociological orientation. With the approach used in the second part, when studying the viability of investments made with these programs, not only does this work not conform to the information provided by official evaluations, it aspires to overcome them. It could be said that this study aims to evaluate the evaluations.

Although Navarro, Cejudo, and Cañete $[16,17]$ have worked similarly to the aforementioned approach, by limiting their studies to the analysis of failed projects (an issue also analyzed in this paper), they leave aside those other investments that for different reasons, could be kept operational, although their profitability is clearly questioned by their promoters. This is where this research is of great interest; evaluating the real feasibility of all the projects promoted, based on the evaluation of those who participated in the implementation of these programs with their investments. Before reaching the second part of the work, this research analyzes how these programs contribute to the economic diversification of rural areas. When studying this issue, it is fundamental to be very aware of the economic resources that these programs can count on and their real capacity for action.

Therefore, based on the methodology of the case study, the objective of this research was to study the practical implementation of these programs based on two fundamental questions: (a) How do these programs contribute to the economic diversification of rural areas, in what productive sectors are investments made?; and (b) What is the viability of the actions carried out? 
This research aims to expand the knowledge of the true scope of rural development programs. The results obtained can contribute to the interest shown by this type of policy, both by academics and by those who work from a technical or political point of view, in their management and design.

Once the objectives of this research are set, note that due to the heterogeneity of rural spaces, the impacts of rural tourism have been studied from many other perspectives. To cite some examples, from a national or supra-regional level, Giannakis [18] studied the role of tourism in the rural development of Cyprus; Haghiri and Okech [19] analyzed the relevance of agro-tourism in rural development in the Canadian regions of Newfoundland and Labrador; Giacco et al. [20] studied the same issue for the whole of Italy. If smaller geographic areas are taken as reference, Ciolac et al. [21], Garau [22], Shin et al. [23], or Lakner et al. [24] could be cited, who by using case study methodology, respectively analyze several aspects of the impacts of tourism on the Apuseni mountains area (Romania), the Marmilla region in the Island of Sardinia, the Korean counties of Jeongseon-gun and Gangwon-do, or the area of Lake Balaton in Hungary.

In accordance with the mentioned heterogeneity of the rural environment, this work should be understood as one more contribution to the study of the impacts of rural tourism; however, in this case, within the framework of European rural development programs. In this last context, in order to justify the interest of this investigation, it is necessary to highlight two elements: (1) La Vera belongs to the Spanish region of Extremadura. As pointed out by González [25], the characteristics of this region make it an ideal framework to study the effects of European rural development policy. Its rural nature, its regressive demographic trends, its ageing population, a per capita income below the Spanish average, and a greater dependence on agricultural activity and employment are the characteristics that stand out. (2) Within this regional scenario, the Association for the Development of the Region of La Vera (ADICOVER) candidacy stood out in the selection process of Local Action Groups (LAGs) that accessed the management of PRODER I. This candidacy was the second most regarded by the Regional Selection Commission, which denotes the maturity of its development strategy. These reasons reinforce the fact that the case of La Vera may be of special interest for other territories, and especially for those that share its characteristics and problems.

After this introduction, the next point reviews the evolution of the LEADER and PRODER programs, the third section addresses the methodology of the research, the fourth section shows the results obtained, and the conclusions of the investigation are discussed in the fifth section.

\section{Rural Development and Economic Diversification as Objectives of the European Union}

At the beginning of the 1980s, there was evidence of an exhaustion of an agricultural productivity model that had determined the functions of the European rural environment since the 1950s. The Commission raised the need to replace an approach based on agricultural development for another one focused on rural development. Among many others [26], the report "Perspectives for the Common Agricultural Policy" [27] (better known as the "Green Paper"), the Communication "The Future of Rural world" [28], or the study "The Development and Future of the Common Agricultural Policy" [29] were some of the documents that materialized the new approaches of the European Commission in the rural environment.

The agricultural problem ceased to be understood as something sectoral, and was considered an issue of the rural environment as a whole. The inability of agriculture to articulate the rural economy on its own was considered evident [30]. The Commission considered the economic diversification of rural areas a priority, with the aim of retaining the population and complementing agricultural income. Defining those rural development strategies was not easy; great resistance by farmers regarding the modification of subsidy systems typical of the agricultural development model [31] had to be overcome, as well as reconciling the urban population's conservationist desires with the productive aspirations of rural locals [32].

In March 1991, the Commission approved the LEADER I initiative [33]. As the European Economic and Social Committee recognized, this initiative emerged in a context in which "the inability 
of Structural Funds to achieve the economic and social cohesion referred to by the Single Act" [34] was clear. LEADER proposed an approach based on a management system and a novel development model [35]. Several authors have studied this approach [36,37], highlighting its sustainable and multisectoral nature. For this initiative, the quality of the natural resources will make the territories more competitive in purely economic aspects, but also in other respects, such as their specificity and identity. Based on its multisectoral nature, the LEADER approach aims to take advantage of numerous productive activities carried out by the different sectors with a real presence or potential in a region, accepting the idea that "economic diversification is the only possibility that many rural areas have today to survive" [38] (p. 88).

Despite its experimental nature, its limited resources, and its clearly secondary nature with regard to regional or agrarian policy, the implementation of LEADER I was valued very positively by those regions in which it was applied [39]. The explanation for the apparent contradiction between resources and results is found in the methodology applied. In fact, several studies carried out often highlight not so much the material achievements derived from a given investment, but the virtues inherent to the LEADER approach. This was so much the case that González Regidor goes as far as saying: "the disappearance of the program would have fewer consequences for the development of many rural areas than the method itself" [40] (p. 50).

Based on those results, in June 1994, the Commission approved the LEADER II initiative [41], with which it went from 217 LAGs to about 1000 [42]. In addition, given the limited resources of LEADER II, Spain approved the PRODER I program [43], so that the Objective 1 regions that had not been beneficiaries of LEADER II could access rural development programs. The philosophy and methodology of the PRODER program is that of the LEADER initiative. Despite these new calls, at a national level in the period 1996-2001, the resources allocated to rural development amounted to 6.4 billion euros, of which only $12.5 \%$ were allocated to LEADER II and PRODER I programs, leading Colino and Martínez [44] to state that "the community discourse contains a big fuss about rural development for nothing" (p. 92). In Extremadura, during that same period, LEADER II and PRODER I represented only $6.5 \%$ of the total of European and national investment executed in its rural areas [45]. That percentage would even be lower if it took into account the transfers from the European Agricultural Guarantee Fund (EAGF).

In the second half of the 1990s, two new milestones reinforced the rural development model of these programs: in 1996, a European Conference on Rural Development was held in Cork; and a year later, the conclusions of that conference were considered by the European Commission in Agenda 2000 [46]. Agenda 2000 consolidated rural development as the second pillar of the CAP, and it supported the commitment of European institutions to the economic diversification of the rural environment [47]. However, when the European Council approved the financial perspectives for the 2000-2006 period in Berlin in 1999, it maintained the budget for rural development in the same terms as in the previous six-year period: barely $11 \%$ of the resources allocated to the CAP and about $4.5 \%$ of the European budget [48], without this serving to avoid "that rural development ceases to be like the Cinderella of the CAP" [49]. For this period and taking the EU-15 as reference, Álvarez-Coque [50] quantified what was allocated to rural development policies as 51.5 billion euros, of which only about 2 billion euros corresponded to the LEADER initiative. Of the 49.5 billion euros left, only $10 \%$ were unrelated to agricultural activities, which is clearly in contradiction with its original goal to create jobs outside the primary sector.

In order to understand the agrarization of rural development policies, the completion of the Uruguay Round of the General Agreement on Tariffs and Trade (GATT) must be considered. The agricultural issue was the subject of intense negotiations there. By considering agricultural measures like rural development, the European Union sought to "camouflage" part of its support of agriculture within a matter that would not be subject to the requirements of the final agreement [51-53].

Despite its limited resources, during the first half of the 2000s, the LEADER initiative was renewed with the call for LEADER+ [54], and in Spain, the PRODER program also had continuity with the 
application of its second call [55]. In this period, the celebration in Salzburg of the Second European Conference on Rural Development [56] constituted another milestone. The Salzburg proposals resulted in the approval of the European Fund for Rural Development (EAFRD), which was created in order to finance rural development programs. Council Regulation no. 1698/2005 defined the action of the EAFRD during the 2007-2013 period. In those six years, Rural Development Programs (RDPs) were articulated around three axes, and what until then had been a community initiative turned into the fourth axis of a methodological nature called the "LEADER Approach", with which the community institutions materialized their interest in this model of rural development.

During the 2007-2013 period, resources allocated to rural development were again severely limited. Although at least $5 \%$ of the EAFRD funds were used in applying the LEADER approach, several authors $[57,58]$ questioned the compliance of that requirement, and even considered the investments aimed at the LEADER approach as "absolutely marginal and even ridiculous" [59]. However, in relation to the scarce resources allocated to rural development programs, the IESA forum [60] proposes to change the way of dealing with problems in the rural world, overcoming the sectoral policies of rural development through other more comprehensive territorial development policies. The IESA forum considers investments in the road network, health, or education more important for many rural territories than achieving a rural development program. In similar terms to the IESA forum, other authors [61] argue that the rural world requires coordination between the cohesion policy and the CAP. In this coordination in favor of regional development, the rural development programs studied would be part of a smaller scope of actions aimed at promoting entrepreneurial capacity and intangible resources of the territory.

For the period underway (2014-2020), the funding of rural development is ruled by Regulation 1305/2013 of the European Parliament and of the Council. However, the communication "The future of food and agriculture. Trends and Challenges" [62] reopens the debate about agrarian and rural development policy. In this context, the Agriculture Commissioner is quick to highlight the importance of rural development programs and of ensuring their continuity [63].

\section{Methodology and Scope of the Investigation}

In his works on the case study, Yin [64] recommends applying this methodology in situations where the limits between the phenomenon to be studied and its context are not clearly defined. This is what happens in the case under analysis: it is not possible to de-link the tourist potentialities of La Vera with the proliferation of tourism investments in that region; both elements are interrelated and mutually conditioned.

To respond to the two questions made at the end of the introduction, this research uses the cited methodology, albeit with different methods for each of them $[65,66]$. In the first case, the analysis does not differ greatly from that used by various authors mentioned in the introduction. However, the feasibility of the actions performed is where this research aims to transcend those carried out so far. Toward this second purpose, Yin [67] argues that qualitative research tools such as conducting interviews can improve the understanding of the information provided by the interviewee, by allowing interaction and for adequate contextualization of their opinions. Thanks to this, the researcher can contribute new ideas that help to explain the subject matter of study.

\subsection{Geographical and Temporary Scope of the Investigation}

The region of La Vera has a series of characteristics that make it be considered a relevant case with which to analyze the consequences of the application of rural development programs. Methodologically, it is essential: (a) for the chosen case to have its clear limits; and (b) for the case to be valid to contrast what is to be studied. La Vera fulfils these conditions.

It is a region with well-defined borders. It is located in the northeast of the province of Cáceres (Autonomous Community of Extremadura, Spain), it borders to the north with the Sierra de Gredos 
and the Valle del Jerte; to the east with the province of Ávila; to the south with the Tiétar River; and to the west with the region of Plasencia (Figure 1).

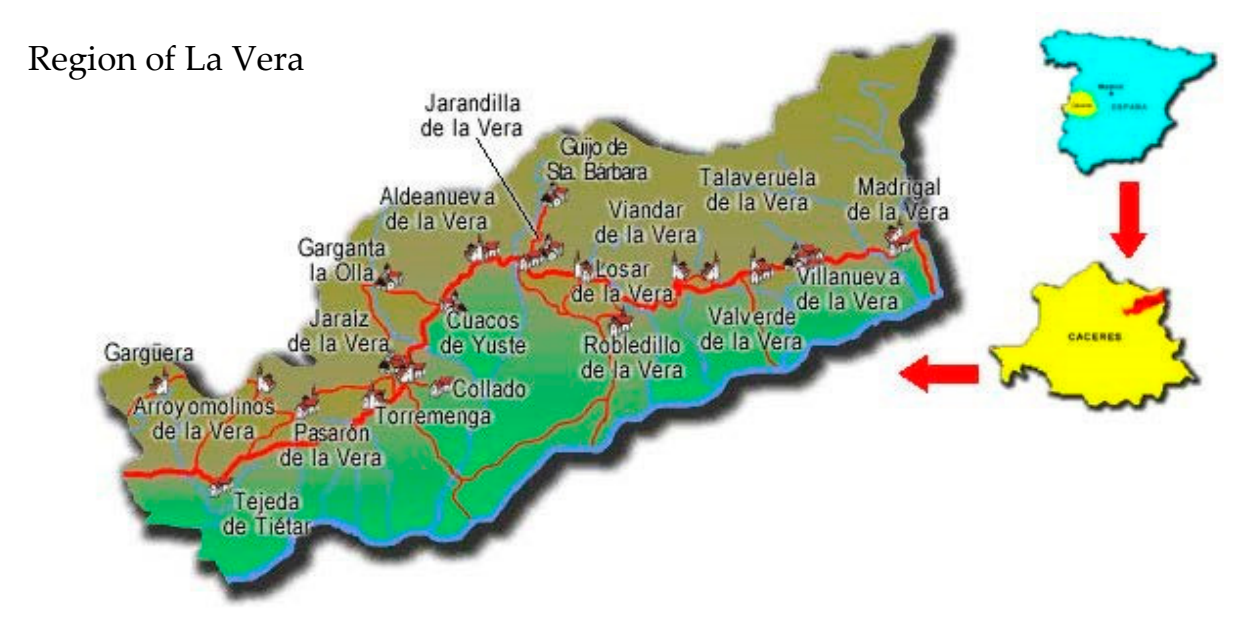

Figure 1. Limits and location of the scope of study.

La Vera has a series of characteristics that have favored the implementation of the rural development policies studied. The following are highlighted:

- A great potential for the development of rural tourism thanks to the valuable natural and scenic resources of the Sierra de Gredos, a rich architectural and cultural heritage, and the relative proximity to the Community of Madrid. Given these resources, the choice of La Vera as an object of study allows us to analyze the difficulties faced by the territories that, when addressing a development strategy, must implement large natural and heritage resources within the strategy.

- The existence of a long tradition in the production of a series of products very characteristic of the area such as paprika, tobacco, or goat cheese, susceptible to greater agrarian valorization.

Regarding the temporal scope of the investigation, analyzing a rural development strategy and understanding the problems that are faced by its application and its possible effects requires perspective. Therefore, the proposed analysis refers to the two editions of the PRODER program in the second half of the 1990s and the beginning of the 2000s, which is a sufficiently long period for these programs to be able to produce results and to analyze the long-term viability of the implemented projects.

\subsection{Interviews Conducted and Sample Selection}

Achieving the objectives of the investigation requires fieldwork in which the main source of information was interviews with the promoters of the productive investments. Regarding the type of interview conducted, semi-structured interviews were considered to be the most appropriate model since they are not a closed instrument, unable to incorporate those evaluations of interest by the interviewees; and at the same time they allow for processing the information obtained.

The questionnaire used to interview is divided into four blocks. The first one collects general information about the project (purpose of the investment made, contribution received, the way in which the PRODER aid improved their company, etc.); this block concludes with the promoters' evaluation about the real viability of their projects. The second block obtains the interviewee's opinion regarding the articulation of the sector in the region and the contribution of PRODER to it. The third section focuses on the contribution of PRODER to the development of the region, its economic diversification, population retention, income level, etc. Finally, the questionnaire includes a last section in which interviewees could make any other comments.

Regarding the promoters that could be object of interview, it is necessary to clarify that within the analyzed programs, there are two types of measures: non-productive measures, financed with public 
funds (recovery of heritage, conservation of the environment, and operating expenses); and productive ones, that mainly include the projects of private developers (rural tourism, Small and medium-sized enterprises (SMEs), and agrarian valorization). Among the projects carried out under this second type of measure, before starting the interview phase, it was necessary to select a sample of the actions that could have the greatest interest. The criteria applied to select that sample were: (a) that the main source of financing and boosting of the action were private; (b) that the subsidy received was at least $12,000 €$; and (c) that the contribution of PRODER accounted for at least $20 \%$ of the investment. Table 1 shows the number of private projects undertaken in each productive measure (which would constitute the framework of the sample) and among these, those that fulfil the above-mentioned criteria and make up the sample for conducting interviews. In addition, it also includes the total investment of these projects, as well as the percentage represented by the projects included in the sample.

Table 1. Projects that constitute the sample and percentage of investment represented.

\begin{tabular}{ccccc}
\hline Measures & $\begin{array}{c}\text { Private } \\
\text { Projects }\end{array}$ & $\begin{array}{c}\text { Project } \\
\text { Samples }\end{array}$ & $\begin{array}{c}\text { Investment of } \\
\text { Private Projects }\end{array}$ & $\begin{array}{c}\text { \% Investment Private } \\
\text { Project Samples }\end{array}$ \\
\hline $\begin{array}{c}\text { Rural Tourism } \\
\text { Small and medium-sized }\end{array}$ & 34 & 24 & $3,572,527.78 €$ & 89.02 \\
enterprises (SMEs), crafts, services & 28 & 12 & $1,635,948.89 €$ & 68.06 \\
Agrarian valorization & 17 & 8 & $1,229,076.70 €$ & 54.77 \\
Total & 79 & 44 & $6,437,553.37 €$ & 77.16 \\
\hline
\end{tabular}

Source: Own elaboration.

Coller [68] defends that the case studies do not base their representation on conducting a large number of interviews, given that their number is limited to the case under study; in their justification, they must resort to analytical arguments. The fact that the projects included in the sample represent $77.16 \%$ of the private project's investment is determinant of the validity of the sample selected.

\subsection{Other Sources of Information and Triangulation of Results}

Although interviews with promoters are the main source of information, in the fieldwork, two other elements that contribute to the knowledge of the case must also be mentioned: (a) Prior study of documentation. This was carried out before the interview phase. This task involved analyzing several documents related to the candidacies submitted by ADICOVER to achieve the management of PRODER; and once the sample was defined, the study of technical information related to the projects that would subsequently be interviewed. (b) On-site evaluation of the projects constituting the sample-even if this involved many journeys, both to the region and to its different localities. The decision was to interview the promoters in the place of the investment. These visits were very useful for conducting the interviews, as they enabled a better understanding of some of the promoters' opinions, the objective of their investments, their motivations, etc.

Once the interviews were completed, a final phase of fieldwork should be highlighted in which, through the triangulation of results, an attempt was made to correct the possible biases in which the interviewees might have incurred. The objective of this activity was to reinforce the rigor of the research, contrasting the previous conclusions of interviews with promoters with the opinions of other agents, who have a deep knowledge of the subject and until now have remained outside the research. Within this last phase, it is worth distinguishing: (a) carrying out interviews with the public authorities of the program (mayors, chair of ADICOVER, and the Commonwealth of municipalities of La Vera). This group of interviewees is linked to public management. Although they do not know the private projects in detail, their opinions can be valuable to capture the perception that the agents that operate in the territory have on the general contribution of PRODER; (b) holding work meetings with the program technicians (ADICOVER manager and staff responsible for the analysis of the projects). 


\section{Analysis of the Application of Rural Development Programs in La Vera}

\subsection{What Sectors Are the Investments Materialized in?}

Table 2 groups the investment in the two PRODER program editions by measures and according to their purpose. As can be seen, the distribution of investments among their measures and the structure of the program seem consistent with the objective of economic diversification.

Table 2. Distribution by measures of the investment made in the Operative Rural Development Program (PRODER) I and II (euros).

\begin{tabular}{ccccc}
\hline & PRODER I & $\%$ & PRODER II & $\%$ \\
\hline CEDER operation and technical assistance & $608,532.98$ & 11 & $666,967.20$ & 12 \\
Recovery and conservation of the environment & $1,227,340.71$ & 23 & $1,097,471.54$ & 20 \\
Total non-productive measures & $\mathbf{1 , 8 3 5 , 8 7 3 , 6 9}$ & $\mathbf{3 4}$ & $\mathbf{1 , 7 6 4 , 4 3 8 . 7 4}$ & $\mathbf{3 2}$ \\
Promotion of rural tourism & $\mathbf{2 , 1 5 7 , 4 9 0 . 1 6}$ & 40 & $\mathbf{2 , 0 7 2 , 6 0 6 . 9 9}$ & 38 \\
SMEs, crafts, and services & $943,459.43$ & 17 & $722,488.60$ & 14 \\
Valorization of agricultural production & $483,272.34$ & 9 & $886,140.89$ & 16 \\
Total productive measures & $\mathbf{3 , 5 8 4 , 2 2 1 . 9 3}$ & $\mathbf{6 6}$ & $\mathbf{3 , 6 8 1 , 2 3 6 . 4 8}$ & $\mathbf{6 8}$ \\
\hline
\end{tabular}

Source: Own elaboration based on the data provided by the Association for the Development of the Region of La Vera (ADICOVER). CEDER: Rural Development Centre.

Any investment generates economic activity; this is a fact both for productive measures (rural tourism; SMEs, crafts, and services; agrarian valorization) and non-productive measures. Regarding the latter, the operating expenses of the CEDER (Rural Development Centre) and technical assistance imply activities of the service sector; or in their case, the recovery and conservation of environment projects mainly involve actions in the construction sector. As shown in the table above, throughout the two program periods, there was no significant transfer of funds among non-productive measures. There were also no large variations in the productive measures, even though two issues should be mentioned: (1) the relevance of rural tourism measures in the two editions of the program; (2) the increase in resources committed to agrarian valorization. Figure 2 represents the distribution of productive investment by measures.

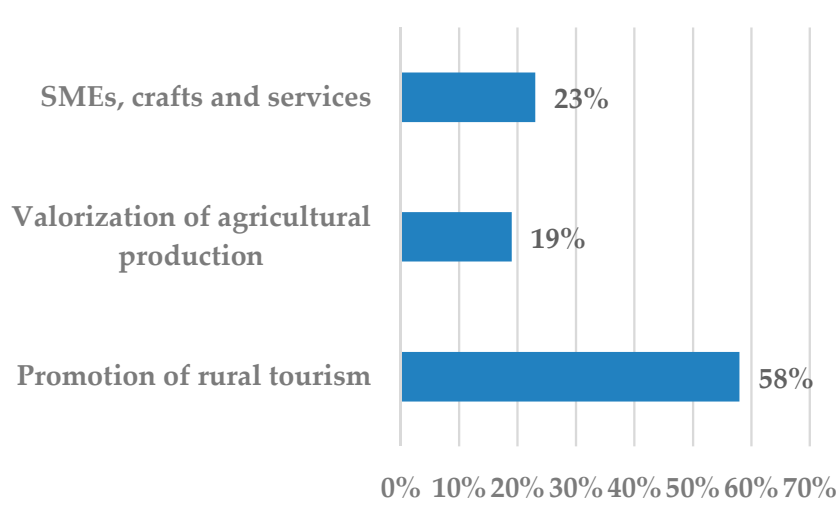

Figure 2. Investment in productive measures PRODER I and II. Source: Own elaboration.

The most outstanding idea of the previous graph is that rural tourism investment accounted for $58 \%$ of all investment in productive measures. This shows the bias of the program towards these types of projects and the relevance that their success will have when assessing PRODER's contribution to the economic diversification of the region. Next, the sectoral distribution of the projects undertaken within the measures included in Figure 2 will be studied. 


\subsubsection{Promotion of Rural Tourism}

A significant concentration of resources in the creation of rural accommodations is noteworthy, although in an initial stage, this could be considered logical given the initial absence of these types of resources. In PRODER II, the type of project financed did not change. Figure 3 shows that investment in complementary activities was insignificant, which is an important subject: the tourist demands quality facilities to stay in, but also activities with which to fully enjoy the tourist resources, which enhance those resources and encourage those who visit them to extend their stays or to wish to return to the area. One of the possible reasons explaining the low number of these types of projects may be that they demand greater originality compared to rural accommodations or a restoration business.

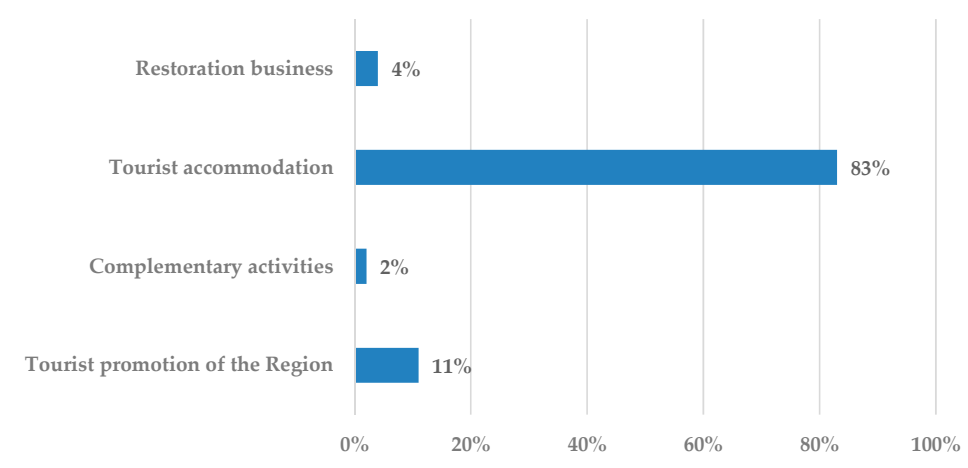

Figure 3. Distribution of investment in rural tourism. Source: Own elaboration.

The resources allocated to restoration businesses also seem scarce, especially when considering that the investment for this type of activity is almost tripled by the investment made in public actions aimed at tourism promotion in the region.

\subsubsection{Small Businesses, Crafts, and Services}

This measure aims to encourage small business initiatives and provision of services. Despite its limited investment, Figure 4 shows that the investments made cover many activities, without any of them (except for graphic techniques) standing out, especially in the volume of resources allocated.

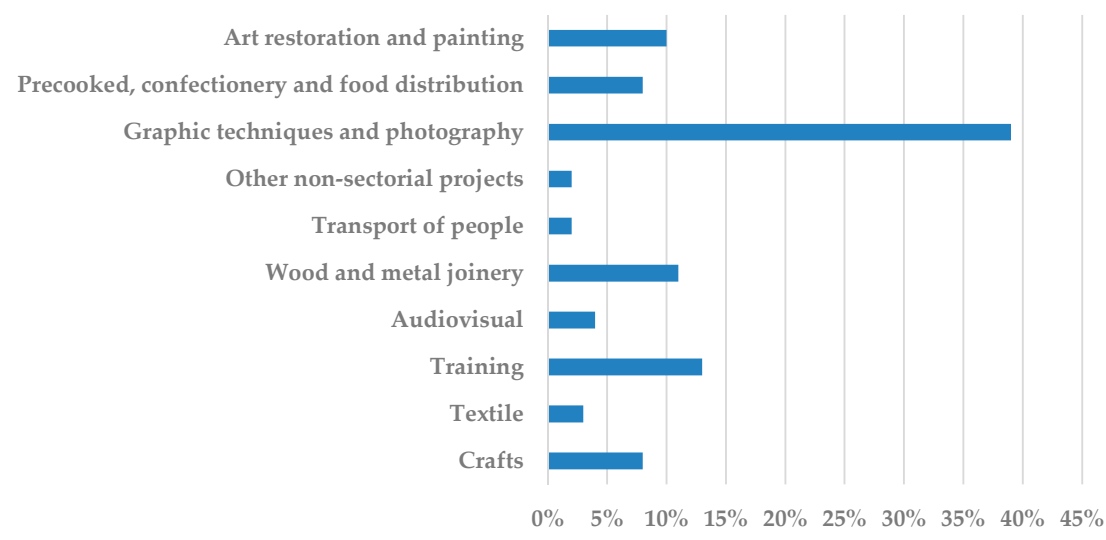

Figure 4. Investment in SMEs, crafts, and services. Source: Own elaboration.

In general, the promoters that presented projects in this measure were endorsed by a long trajectory of running their businesses; the financing received represented a qualitative leap for their companies, allowing for their modernization, the extension of their dimension, and their adaptation to a scenario of greater competitiveness. The most critical conclusion of the projects implemented in this measure is the limited relevance of the actions aimed at the promotion of crafts. 


\subsubsection{Valorization of Agricultural Production}

This measure aims to boost the agro-industrial sector in order to retain on the territory, the added value derived from the transformation of raw materials. Goat cheese is the product that best takes advantage of this measure; most of the investments were received by the cooperative that integrates the goat farmers of the region. This fact makes these actions a good example of the distribution of benefits of agrarian valorization among the local population (Figure 5).

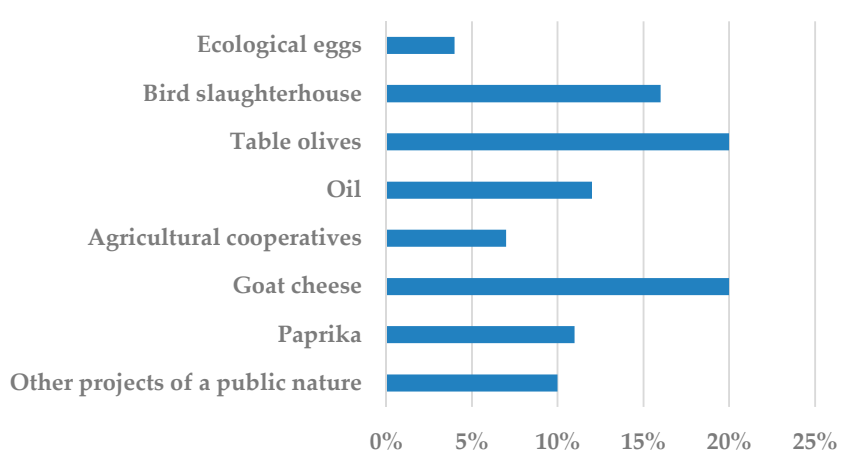

Figure 5. Investment in the valorization of local agricultural production. Source: Own elaboration.

Paprika also finds a useful instrument to modernize its facilities in this program. However, on the negative side, note that for tobacco-one of the most characteristic productions of the region-the program is limited to financing a public project aimed at studying the possibilities of organic tobacco, which barely accounted for $4 \%$ of investment in this measure.

Within this measure, a comment must be made on two of the projects promoted: the poultry slaughterhouse and table olives, which together represent a little more than a third of the investment. In both cases, the raw material comes from outside the region, which means that the objective of adding value to the local agricultural production is not being fulfilled, although it is true that support for these projects is a valid option to diversify the regional economic activity.

\subsection{What Is the Viability of the Actions Carried out in the Different Productive Measures?}

\subsubsection{Projects that Ceased Their Activity after the Period of Eligibility}

Table 3 shows the number of projects that make up the sample, distinguishing between those that created new businesses and those that modernized existing ones. Based on this, those projects that ceased their activity in each of the productive measures are quantified.

Table 3. Classification of failed projects according to their typology.

\begin{tabular}{|c|c|c|c|c|}
\hline \multicolumn{3}{|c|}{ Measures and Typology of Projects } & \multirow{3}{*}{$\begin{array}{c}\text { Sample } \\
15 \\
5\end{array}$} & \multirow{3}{*}{$\frac{\text { Failed }}{4}$} \\
\hline \multirow{4}{*}{ Rural Tourism } & \multirow{2}{*}{ Accommodation } & New Creation & & \\
\hline & & Modernization & & \\
\hline & Restaurants & $\begin{array}{l}\text { New Creation } \\
\text { Modernization }\end{array}$ & 3 & \\
\hline & Other activities & $\begin{array}{l}\text { New Creation } \\
\text { Modernization }\end{array}$ & 1 & 1 \\
\hline \multirow{2}{*}{\multicolumn{2}{|c|}{ SMEs, crafts, and services }} & New Creation & 2 & 2 \\
\hline & & Modernization & 10 & \\
\hline \multirow{2}{*}{\multicolumn{2}{|c|}{ Agrarian valorization }} & New Creation & 1 & \\
\hline & & Modernization & 7 & \\
\hline \multicolumn{3}{|c|}{ Total } & 44 & 7 \\
\hline
\end{tabular}

Source: Own elaboration. 
Despite the specialization of the program in rural tourism, one-fifth of the actions that make up the sample in these projects had ceased in their activity; this involved about $20 \%$ of the investment and of the subsidies granted for these actions. On the contrary, in the other two productive measures, only $10 \%$ of the actions were unsuccessful, which implied $4.4 \%$ of the investment and $5.7 \%$ of the subsidies granted; these last ones were actions that resulted in the creation of new companies and not the modernization of previously existing businesses. Failed projects in rural tourism deserve further comment because the profile of this investment is well-defined: four of those actions were aimed at the new creation of accommodation. In addition, the only project aimed at developing complementary activities for tourists has not been able to maintain its activity in the long term.

\subsubsection{Results of the Interviews and Assessment by the Promoters of the Viability of Their Businesses}

As shown in Table 4, leaving aside failed projects, only three interviews had to be turned down given the inaccessibility of the promoters.

Table 4. Classification of projects according to their typology and feasibility.

\begin{tabular}{|c|c|c|c|c|c|c|}
\hline \multirow{2}{*}{\multicolumn{3}{|c|}{ Measures and Typology of Projects }} & \multirow{4}{*}{$\begin{array}{c}\begin{array}{c}\text { Successful } \\
\text { Projects }\end{array} \\
11 \\
5\end{array}$} & \multirow{4}{*}{$\begin{array}{c}\text { Interviews } \\
10 \\
5\end{array}$} & \multicolumn{2}{|c|}{ Viability } \\
\hline & & & & & \multirow{3}{*}{$\begin{array}{c}\text { Unviable } \\
10\end{array}$} & \multirow{3}{*}{$\begin{array}{c}\text { Viable } \\
0 \\
5\end{array}$} \\
\hline \multirow{4}{*}{ Tourism } & & New Creation (N.C.) & & & & \\
\hline & Accommodation & Modernization (M) & & & & \\
\hline & & New Creation (N.C.) & & & & \\
\hline & Restaurants & Modernization (M) & 3 & 3 & & 3 \\
\hline \multirow{2}{*}{\multicolumn{2}{|c|}{ SMEs and services }} & New Creation (N.C.) & & & & \\
\hline & & Modernization (M) & 10 & 9 & 1 & 8 \\
\hline \multirow{2}{*}{\multicolumn{2}{|c|}{ Agrarian valorization }} & New Creation (N.C.) & 1 & 1 & & 1 \\
\hline & & Modernization (M) & 7 & 6 & & 6 \\
\hline \multicolumn{3}{|c|}{ Total } & 37 & 34 & 11 & 23 \\
\hline
\end{tabular}

Regarding the viability of their businesses, the responses of the tourism promoters must be differentiated from those of the other two measures. In the first case, most tourist accommodation promoters $(62 \%)$ considered that their projects were not viable. Here, there must also be a differentiation between the pessimism of those who developed a project of new construction of rural accommodation and the relative optimism shown by those who modernized their businesses. The results obtained by the newly created rural accommodation projects were negative, to the point that between the failed ones and those whose viability is clearly questioned, none of these projects would have been successful.

Although the total number of interviews was thirty-four, given the orientation of the research towards the analysis of the limitations of rural tourism, it is necessary to refer to the content of the ten interviews to promoters of new rural accommodations. To safeguard their anonymity and organize the story that is included below, each of the interviewees was numbered.

First, it is worth mentioning the interviews of two promoters who recognized that their businesses are not profitable, and who work exclusively in their management. Both of them come from an urban area where they developed their professional or academic life, and both made significant investments with their own resources. When Interviewee 1 was asked if he would have started his project without PRODER's support, he replied: "At that time, yes, since I did not know the reality of the sector, but with the knowledge I have now, I would have done something different". Regarding the viability of rural accommodation, he states: "those who decided to start businesses because of a subsidy are already closed because in the end, the numbers do not add up"; and when asked about the situation of the sector, he concludes: "if a study were made on the viability of rural tourism businesses, the result would be that the vast majority of them are unviable". In his case, "creating a Rural Hotel was the way to change his life, and that was the goal". His project was carried out without resorting to indebtedness, and "thanks to that it survives". 
When Interviewee 2 was asked if he would have started the project without PRODER's aid, he replied: "At that moment no and today still less (... ), in fact, the investment made was not justified by the existing demand"; and continues admitting: "we do not consider the action as a business and now we are paying the consequences, we have reduced all the expenses to the maximum and in spite of this, the numbers do not add up". Regarding the effects that the current crisis may be having on the viability of his business, Interviewee 2 admits that the demand has decreased more than what could be believed according to "official" reports: "the data that are handled by administrations with regard to the occupation level are totally wrong"-something that Interviewee 1 agrees with when considering that: "the statistics that speak of levels of occupation higher than $20 \%$ are false". In addition to the fall in demand due to the economic crisis, Interviewee 2 highlights another factor that hinders the profitability of his business: the excess supply of tourist accommodation promoted by rural development programs such as PRODER. He also cites the latest call for subsidies made by ADICOVER: "where more projects have been presented is in the tourism sector, we are changing the monoculture of tobacco for the tourism monoculture, and we are seeing that rural tourism is not a panacea". In fact, when asked if he believes that PRODER has been able to encourage other people to undertake projects similar to his, he replies: "I am afraid so, in the last edition of ADICOVER, twelve new projects related to tourism were presented and in my opinion they are not sustainable. In the region there is an excess supply of tourist accommodation, a "bubble" around rural tourism has been created and the truth is that 'you can't demand the impossible'; that is, you cannot ask for wonderful accommodation, with huge investments that cannot be maintained, and what about profitability? Tourism is not what it seems and profitability is very limited, it is a complementary source of income, but you cannot make a living only from it".

In spite of that regretful tone used, the considerations of Interviewee 2 serve to confirm the philosophy with which this type of aid arises: to supplement farmers' incomes through modest investments. This research seems to confirm that all those investments that have moved away from this initial philosophy have serious difficulties in offering their promoters acceptable profit margins.

For professional reasons, Interviewee 3 admits to having participated in a number of projects of the creation of rural accommodation. Regarding the characteristics of the investments made, he states: "all the projects that I have designed have been with a much higher projection and quality than the expected yield; the investments made are not justified and can hardly be recovered". This interviewee, when assessing the evolution of his business, states: "10-11 years ago there was more demand for tourism and in addition, it had more purchasing power. Now, tourists arrive at the Rural House and try not to move from there, filling the fridge and spending as little as possible".

Interviewee 4 confirms the supplementary nature of income from tourism: "you cannot live exclusively off a rural tourism business. The winter is very long and the season almost depends on the month of August". Regarding PRODER's ability to encourage other people to undertake projects similar to his own, he answered affirmatively, explaining that in his locality "they were the only ones for decades, while there are currently 3 or 4 more businesses".

Interviewee 5 considers that "in its beginnings, PRODER was essential for the creation of accommodations, but once that first phase was over, it was unclear how to reorient the role of PRODER. More accommodation continued to be created, this implied the oversizing of the sector; currently there is more supply than demand, and this is not because the demand has decreased due to the crisis (which also), it is due to an excess of supply of accommodations.

Interviewee 6 understands that: "we have gone from a situation in which there was no accommodation capacity, to one in which there is an excess of supply; and this occurred before that demand decreased as a result of the economic crisis ( ... ) if I did not have to comply with the requirements of the subsidy, I would consider closing down".

Interviewee 7, also of neo-rural origin, considers that: "there is an excess supply of accommodation places and even so, PRODER continues to subsidize more and more rural tourism projects, oversizing 
the sector ( . . ) currently the level of occupation is very low and his Rural House is for sale. A Rural House is not a business; it is more a way of life".

The same as Interviewees 1 and 7, other promoters of urban origin admit having undertaken their business with the intention of accessing "another way of life". This is also the case of Interviewee 8, who, when asked if he would have started the project without PRODER's support, responds: "Yes, I had lived in Madrid all my life; I did it for a lifestyle in a rural area and for a number of personal factors. PRODER's aid was not the cause of the project. If someone gets involved in an investment of these characteristics because of the subsidy, he does not know what he is doing". Interviewee 8 is a civil servant, who decided to take leave to return to his parents' village and create a Rural House. After a few years, he returns to his job: "if it had been a fantastic business, perhaps, I would have decided not to return ( ... ) if someone thought that tourism would be the remedy for the rural environment, that person was wrong; and concludes: "if you have your mortgage paid, maybe modestly you could continue living off your rural house, but no as a business".

Interviewee 9 values the contribution by PRODER to the rural tourism sector: "Many things have been done. A different question is the real feasibility of these projects; I will never recover the investment made in the rooms $(\ldots)$, whoever wants to make money from rural tourism is mistaken".

Given that the research focuses on analyzing the limitations of tourism as an axis of development of rural spaces, and given the importance that resources allocated to the creation of new rural accommodation have within tourism investments, it was necessary to indicate some of the considerations made by these types of promoters. However, leaving aside these projects, the rest of rural tourism actions provide a very different result. Table 4 shows that there were eight other interviews with promoters that had modernized their businesses: five rural accommodations and three restaurants. All of them considered that their investments were viable. In addition, almost all the projects of SMEs, services and agrarian valorization, were aimed at the modernization of businesses (15 out of 16), and among these, only one of them questioned the viability of the investment.

Table 5 analyses some characteristics of the promoters. If Tables 4 and 5 are compared, it can be concluded that neither sex, level of education, nor origin of the promoters determined the viability of the projects, because for those three measures, the characteristics of the promoters were heterogeneous. It seems that the viability of the projects was determined to a greater extent by the type of project itself: existing business modernization actions or new business creation.

Table 5. Characteristics of the interviewees.

\begin{tabular}{|c|c|c|c|c|c|c|c|c|c|c|}
\hline \multirow{2}{*}{\multicolumn{3}{|c|}{ Typology of Projects }} & \multirow{2}{*}{ Interviews } & \multicolumn{3}{|c|}{ Origin } & \multicolumn{2}{|c|}{ Formation } & \multicolumn{2}{|c|}{ Sex } \\
\hline & & & & Native & Returned & Neorural & Basic & University & Male & Female \\
\hline \multirow{4}{*}{$\begin{array}{c}\text { Rural } \\
\text { Tourism }\end{array}$} & \multirow{2}{*}{ Accommodation } & N.C. & 10 & 4 & 3 & 3 & 5 & 5 & 6 & 4 \\
\hline & & $\mathrm{M}$ & 5 & 5 & & & 5 & & 4 & 1 \\
\hline & Restaurants & $\begin{array}{c}\text { N.C. } \\
\text { M }\end{array}$ & 3 & 3 & & & 3 & & 3 & \\
\hline & Other activities & $\begin{array}{c}\text { N.C. } \\
\text { M }\end{array}$ & & & & & & & & \\
\hline \multirow{2}{*}{\multicolumn{2}{|c|}{ SMEs and services }} & N.C. & & & & & & & & \\
\hline & & M & 9 & 8 & 1 & & 6 & 3 & 6 & 3 \\
\hline \multirow{2}{*}{\multicolumn{2}{|c|}{ Agrarian valorization }} & N.C. & 1 & & & 1 & & 1 & & 1 \\
\hline & & $\mathrm{M}$ & 6 & 6 & & & 6 & & 6 & \\
\hline \multicolumn{3}{|c|}{ Total } & 34 & 26 & 4 & 4 & 25 & 9 & 25 & 9 \\
\hline
\end{tabular}

N.C.: new creation; M: modernization. Source: Own elaboration.

However, the previous table also shows that, regarding the level of education: (1) almost all neorural and returnees had higher education; (2) the promoters that modernized their businesses had basic studies. Regarding their origin: (a) six of the eight neorural or returnee promoters created rural accommodations; (b) in the rest of the measures, the great majority of promoters were native. Finally, in relation to sex: the measure of agrarian valorization records only one project promoted by a woman, while four of the ten projects of the creation of accommodations were promoted by women. 


\section{Discussion}

Rural development programs have never lost their experimental nature with which they emerged in the mid-1980s, and this hinders their ability to transform the rural reality. A good example of this is the case under analysis: after two editions of the PRODER program, its total investment amounted to $7,265,458.41 €$. By itself, that investment does not have the capacity to substantially change the development of La Vera region; this is shown in Table 6.

Table 6. Active employed in La Vera (1991-2004).

\begin{tabular}{ccc}
\hline Economic Sector & $\mathbf{1 9 9 1}$ & $\mathbf{2 0 0 4}$ \\
\hline Agriculture & $38.9 \%$ & $46.9 \%$ \\
Industry & $11.4 \%$ & $6.9 \%$ \\
Construction & $15.6 \%$ & $15.9 \%$ \\
Services & $34.1 \%$ & $30.3 \%$ \\
& $100.0 \%$ & $100.0 \%$ \\
\hline
\end{tabular}

Source: National Institute of Statistics and Studies Center Caja España [69].

Contrary to the economic diversification desired, the previous table shows how the percentage of employed people in the primary sector increased by $8 \%$ to the detriment of those employed in the secondary and tertiary sectors. Although the PRODER investment focused on service projects (not only on rural tourism actions, it also invested in SME projects), the percentage of assets occupied in this sector decreased. The same happened in the industrial sector, despite the fact that in this activity, there were no failed projects and its promoters recognized the viability of their investments.

When studying the results of these programs, their true capacity for action must be taken into account. The second epigraph of this document summarizes the LEADER and PRODER origin and shows that the resources assigned to these programs were insufficient to address their objectives; to the point that some authors [70] unlink the evolution of rural areas from the existence of these types of programs. Although Nieto and Gurría [2] agree with this position, Nieto and Cárdenas [3-8] later seem to forget those previous investigations. In their studies on the impact of LEADER and PRODER programs in Extremadura, these authors show how in Extremadura the LAG's located in mountain areas (or with great natural resources) specialize their development strategies in rural tourism, and they link this fact with the scarce development achieved by these regions. Would the reality of these regions be different today if LEADER and PRODER investments were concentrated in sectors other than rural tourism? These authors agree with this research by questioning the capability of tourism investments to become the engine of economic development. However, as argued in the introduction, the limitations of the approach and methodology applied determine the empirical foundation of their conclusions.

The sociological investigations cited in the Introduction [10-12] focus on the relevance that the implication of the social capital of the region has for the successful application of rural development programs. This is an interesting question, but it leaves aside the importance that the attraction of human resources external to the region could also have: the neorurals and returnees. Cejudo, Navarro, and Camacho [13] recognize as a weakness of their work the fact of not having taken promoter origin into account. This research demonstrates the relevance that promoters of neorural and returnee origin have in the execution of tourism investments.

Muresan et al. [14] show a positive assessment of the rural population with respect to the possibilities that rural tourism offers. The tourist activity can transfer a certain image of dynamism; in the triangulation of its results, this investigation shows how public representatives, when assessing the results of PRODER, especially value the investments in rural tourism. Nevertheless, the views of a population disconnected from the tourist activity should not be confused with the qualified opinion of those who promote and manage investments in this sector. 
Quaranta, Citro, and Salvia [15] highlight the relevance of the interconnection between the different tourism projects. According to these authors, accommodation or catering investments cannot be understood by promoters as something unrelated to complementary activities. This may be related to the failure that these last types of projects have had in La Vera.

In general terms, the works that analyze the impacts of rural tourism on different regions and from different perspectives [18-24] highlight the potential of the tourism activity. Faced with this "optimistic" vision, this research aims to analyze, let us say, the "pessimistic" side of the issue: the limitations of tourism as a development tool. Perhaps the differences in the conclusions obtained lie in the approaches used. As a general rule, the aforementioned analyses try to evaluate the economic impact that the influx of visitors may have on other economic activities typical of rural areas. For this, they resort to different methodologies in which different indicators or economic aggregates are implemented. Faced with this general approach, this research seeks to understand the individual logic followed by economic agents who get involved in making tourism investments. Inevitably, these decisions can only be explained and understood within rural development strategies, which in the European Union, have a micro-regional context as a territorial basis. Hence, the region of La Vera is the scope of analysis used in this case study.

\section{Conclusions}

The investigation shows some issues that should be taken into account by those involved in the implementation of the programs studied:

Regarding the distribution of resources between measures and projects, the chosen case shows a significant concentration of investments in the new construction of rural accommodations; with the added handicap that these actions have the highest number of failed projects, and none of the promoters that keep their businesses open consider their investments viable. The promoters of these actions think that PRODER could have contributed to the oversizing of the sector. The chosen case seems to show that the promotion of tourism as an instrument of rural development must start from a prudent assessment of existing tourist resources and the demand that they can generate.

There were no failed projects of agrarian valorization, and the ones existing in promoting SMEs were inferior to those of rural tourism. Furthermore, the actions carried out within those two measures were spread among a greater number of sectors or activities, which seemed to contribute more effectively to the economic diversification of the region than rural tourism promotion.

In view of the implementation of these programs in other territories, if this research had to conclude with a recommendation regarding the type of project that shows greater viability, the answer would be clear: modernization investments in previously existing businesses. Regardless of the sector in which their investments were made, the characteristics of the promoters of these types of projects were given by: (a) their native origin; and (b) their low level of training. This characterization can help to define other support actions towards these promoters (e.g., training measures).

No cause-effect relationship has been detected between the characteristics of the promoters and the viability of their businesses. However, in the creation of new rural accommodation: (a) Neorural and returnee origin promoters had a greater presence. This raises a new element to be taken into account at the moment of proposing a subsidy grant: the motivation of the promoter. Neorural and returnee promoters indicated that the fundamental purpose of their investment was not to obtain a return, but their desire to "change their lives". This fact may be relevant when explaining why these types of projects remain operational despite their low profitability. (b) The aforementioned actions had a greater number of female promoters. If in a territory the main objective of these programs were to retain the female population or to attract new human resources, these conclusions could condition the type of strategy to be implemented.

Regarding its limitations, it must be taken into account that given the methodology used, the conclusions of the research cannot be extrapolated statistically. However, this study deepens the knowledge of rural development programs and the difficulties that may arise in their practical 
application. Their conclusions may be of interest, both for any region involved in the management of these programs, and in particular, for those areas that share the characteristics of La Vera, which must face the challenge of implementing important natural resources in their development strategy.

Author Contributions: Conceptualization, Methodology, Formal Analysis, Investigation and Resources, F.J.C.-Á., M.d.l.C.d.R.-R., J.Á.-G., and A.D.-S.; Writing-Original Draft Preparation and Writing-Review \& Editing, F.J.C.-Á., M.d.l.C.d.R.-R., J.Á.-G., and A.D.-S.; Project Administration and Supervision, J.Á.-G. and M.d.l.C.d.R.-R.

Funding: The dissemination of this work has been possible thanks to the funding granted by the European Regional Development Fund (ERDF) and by the Junta de Extremadura to the DESOSTE research group through the aid with reference GR18052.

Conflicts of Interest: The authors declare no conflict of interest.

\section{References}

1. Navarro, F.; Cejudo, E.; Maroto, J.C. Aportaciones a la evaluación de los programas de desarrollo rural. Boletín de la Asociación de Geógrafos Españoles 2012, 58, 349-379.

2. Nieto, A.; Gurría, J.L. El modelo rural y el impacto de los programas Leader y Proder en Extremadura (Propuesta metodológica). In Scripta Nova. Revista Electrónica de Geografía y Ciencias Sociales; Universidad de Barcelona: Barcelona, Spain, 2010; Volume XIV, pp. 1-25.metodológica). In Scripta Nova. Revista Electrónica de Geografía y Ciencias Sociales; Universidad de Barcelona: Barcelona, Spain, 2010; Volume XIV, pp. 1-25.

3. Nieto, A.; Cárdenas, G. El método Leader como política de desarrollo rural en Extremadura en los últimos 20 años (1991-2013). Boletín de la Asociación de Geógrafos Españoles 2015, 69, 139-162.

4. Nieto, A.; Cárdenas, G. 25 años del método Leader en Extremadura. Su estudio mediante técnicas SIG y análisis multivariado. Revista Internacional de Ciencia y Tecnología Información Geográfica 2016, 18, 125-146.

5. Nieto, A.; Cárdenas, G. Análisis del Método Leader (2007-2013) en Extremadura mediante técnicas SIG y Análisis Multivariado. Cuadernos Geográficos 2017, 56, 148-171.

6. Nieto, A.; Cárdenas, G. Towards Rural Sustainable Development? Contributions of the EAFRD 2007-2013 in Low Demographic Density Terriories: The Case of Extremadura. Sustainability 2017, 9, 1173.

7. Nieto, A.; Cárdenas, G. 25 años de políticas europeas en Extremadura: Turismo rural y método Leader. Cuadernos de Turismo 2017, 39, 389-416. [CrossRef]

8. Nieto, A.; Cárdenas, G. El método Leader en Extremadura en los últimos 25 años. In Treinta años de Política Agraria Común en España. Agricultura y Multifuncionalidad en el Contexto de la Nueva Ruralidad; Ruiz, A., Serrano, M., Plaza, J., Eds.; Asociación de Geógrafos Españoles: Ciudad Real, Spain, 2016; pp. 399-412.

9. Márquez, D.; Foronda, C.; Galindo, L.; y García, A. Eficacia y eficiencia de Leader II en Andalucía: Aproximación a un índice-resultado en materia de turismo rural. Geographicalia 2005, 47, 137-152.

10. Garrido, F.; Moyano, E. Capital social y desarrollo en zonas Rurales. Un análisis de los programas Leader II y Proder en Andalucía. Revista Internacional de Sociología 2002, 60, 67-96. [CrossRef]

11. Ramos, E.; Garrido, D. Estrategias de desarrollo rural territorial basadas en las especificidades rurales. El caso de la marca Calidad Rural en España. Revista de Estudios Regionales 2014, 100, 101-129.

12. Navarro, F.; Woods, M.; Cejudo, E. The Leader Iniciative has been a victim of its own success. The decline of the bottom-up approach in rural development programmes. The cases of Wales and Andalusia. Sociologia Ruralis 2016, 56, 270-288. [CrossRef]

13. Cejudo, E.; Navarro, F.A.; Camacho, J.A. Perfil de los beneficiarios de los Programas de desarrollo rural en Andalucía. Leader + y Proder II (2000-2006). Cuadernos Geográficos 2017, 56, 155-175.

14. Muresan, I.; Oroian, C.; Harun, R.; Arion, F.; Porutiu, A.; Chiciudean, G.; Todea, A.; Lile, R. Local Residents Attitude toward Sustainable Rural Tourism Development. Sustainability 2016, 8, 100. [CrossRef]

15. Quaranta, G.; Citro, E.; Salvia, R. Economic and Social Sustainable Synergies to Promote Innovations in Rural Tourism and Local Development. Sustainability 2016, 8, 668. [CrossRef]

16. Navarro, F.; Cejudo, E.; Cañete, J.A. Balance de la Iniciativa Comunitaria de desarrollo rural tras 25 años. Continuidad de las empresas creadas con apoyo de Leader I y II. El caso de las Alpujarras. In Treinta años de Política Agraria Común en España. Agricultura y Multifuncionalidad en el Contexto de la Nueva Ruralidad; Ruiz, A., Serrano, M., Plaza, J., Eds.; Asociación de Geógrafos Españoles: Ciudad Real, Spain, 2016; pp. 385-398. 
17. Cañete, J.A.; Cejudo, E.; Navarro, F. Proyectos fallidos de desarrollo rural en Andalucía. Boletín de la Asociación de Geógrafos Españoles 2018, 78, 270-301. [CrossRef]

18. Giannakis, E. The role of rural tourism on the development of rural areas: The case of Cyprus. J. Rom. Reg. Sci. 2014, 81, 38-53.

19. Haghiri, M.; Okech, R. The role of the agritourism management in developing the economy of rural regions. Tour. Manag. Stud. 2011, 1, 99-105.

20. Giaccio, V.; Mastronardi, L.; Marino, D.; Giannelli, A.; Scardera, A. Do Rural Policies Impact on Tourism Development in Italy? A Case Study of Agritourism. Sustainability 2018, 10, 2938. [CrossRef]

21. Ciolac, R.; Adamov, T.; Iancu, T.; Popescu, G.; Lile, R.; Rujescu, C.; Marin, D. Agritourism: A Sustainable Development Factor for Improving the "Healt" of Rural Settlements. Case Study Apuseni Mountains. Sustainability 2019, 11, 1467. [CrossRef]

22. Garau, C. Perspectives on cultural and sustainable rural tourism in a smart region: The case study of Marmilla in Sardinia (Italy). Sustainability 2015, 7, 6412-6434. [CrossRef]

23. Shin, H.; Kim, H.; Son, J. Measuring the Economic Impact of Rural Tourism Membership on Local Economy: A Korean Case Study. Sustainability 2017, 9, 639. [CrossRef]

24. Lakner, Z.; Besan, A.; Merlet, I.; Oláh, J.; Máté, D.; Grabara, J.; Popp, J. Building Coalitions for Diversified and Sustainable Tourism: Two case studies from Hungary. Sustainability 2018, 10, 1090. [CrossRef]

25. González, J. Desarrollo Rural de Base Territorial: Extremadura; Ministerio de Agricultura, Pesca y Alimentación and Consejería Desarrollo Rural Junta Extremadura: Badajoz, Spain, 2006.

26. Valcárcel-Resalt, G. Desarrollo local en España: Utopía o realidad. In Desarrollo Local y Medio Ambiente en Zonas Desfavorecidas; MOPT: Madrid, Spain, 1992; pp. 24-27.

27. European Commission. Perspectives for the Common Agricultural Policy; The Green Paper of the Commission; Green Europe News Flash 33, COM (85) 333; Communication of the Commission to the Concil and the Parliament: Brussels, Belgium, 1985.

28. European Commission. The Future of Rural Society; COM (88) 501; Bulletin of the European Communities, Supplement 4/88; Office for Official Publications of the European Communities: Luxembourg; Brussels, Belgium, 1988. Available online: https:/ec.europa.eu/agriculture/sites/agriculture/files/cap-history/crisisyears-1980s/com88-501_en.pdf (accessed on 11 March 2019).

29. European Commission. The Development and Future of the Common Agricultural Policy; Document drawn up on the basis of COM (91) 100 and COM (91) 258; Bulletin of the European Communities, Supplement 91/5; Office for Official Publications of the European Communities: Luxembourg; Brussels, Belgium, 1991. Available online: https://ec.europa.eu/agriculture/sites/agriculture/files/cap-history/1992-reform/com91-100_en.pdf (accessed on 11 March 2019).

30. Pisani, E. Pour una Agriculture Marchande et Ménagére; Editions l'Aube: Paris, France, 1994; pp. 101-120.

31. OCDE. Formulation de la Politique Rurale. Nouvelles Tendances; OCDE: París, France, 1988.

32. Etxezarreta, M.; Cruz, J.; García, M.; Viladomiú, L. La Agricultura Familiar ante las Nuevas Políticas Agrarias Comunitarias; MAPA Serie Estudios: Madrid, Spain, 1995; pp. 81-83.

33. Comisión Europea: Comunicación por la que se Fijan las Directrices de unas Subvenciones Globales Integradas para las que se Invita a los Estados Miembros a Presentar Propuestas que Respondan a una Iniciativa Comunitaria de Desarrollo Rural (91/C 73/14). Diario oficial de las Comunidades Europeas, $n^{\circ} 73 / 33$ del 19 de marzo de 1991. Available online: https:/eur-lex.europa.eu/legal-content/ES/TXT/PDF/?uri=OJ: JOC_1991_073_R_0033_01\&from=ES (accessed on 11 March 2019).

34. Consejo Económico y Social: Dictamen en Relación al Proyecto de Comunicación de la Comisión por la que se Invita a los Estados Miembros a Presentar Propuestas en el Marco de la Iniciativa Comunitaria Leader. Pleno $280^{\circ}$, celebrado el 18 de octubre de 1990. Available online: http://www.redr.es/es/portal.do?TR=C\&IDR=26 (accessed on 11 March 2019).

35. European Association of Information on Local Development. Evaluate the Added Value of the Leader Approach; Notebook No. 4; Leader European Observatory: Brussels, Belgium, 1999.

36. Cebrián, A. Génesis, método y territorio del desarrollo rural con enfoque local. Papeles de Geografía 2003, 38, 61-76.

37. Cazorla, A.; De los Ríos, I.; Díaz, J.M. La Iniciativa Comunitaria Leader como modelo de desarrollo rural: aplicación a la región capital de España. Agrociencia 2005, 39, 697-708. 
38. Alberdi, J.C. El medio rural en la agenda empresarial: La difícil tarea de hacer partícipe a la empresa del desarrollo rural. Investigaciones Geográficas 2008, 45, 63-91. [CrossRef]

39. Beltrán, C. Mecanismos e instrumentos de la Iniciativa Leader II. In Hacia un Nuevo Sistema Rural; MAPA Serie Estudios: Madrid, Spain, 1995; p. 483.

40. González, J. El método Leader: Un instrumento territorial para un desarrollo rural sostenible. El caso de Extremadura. In Desarrollo Rural de Base Territorial: Extremadura; González, J., Ed.; MAPA and Consejería Desarrollo Rural Junta Extremadura: Badajoz, Spain, 2006; p. 50.

41. European Commission: Communication Setting out Guidelines for Global Grants to Integrated Operational Programs, for Which States Are Requested to Submit Applications for Assistance within a Community Initiative for Rural Development (94/ C 180/12). Official Journal of the European Communities, 1 July 1994. Available online: https://eur-lex.europa.eu/legal-content/ES/TXT/PDF/?uri=OJ:JOC_1994_180_R_0048_01\& from=ES (accessed on 11 March 2019).

42. European Association of Information on Local Development. Local Financing in Rural Territories; Notebook No. 9; Leader European Observatory: Brussels, Belgium, 2000; p. 5.

43. Ministerio Agricultura Pesca y Alimentación. Programa Nacional Proder I; Julio: Madrid, Spain, 1996.

44. Colino Sueiras, J.; Martínez Paz, J.M. El desarrollo rural: Segundo pilar de la PAC. In Política Agraria Común: Balance y Perspectivas; García Delgado, J.L., García Grande, M.J., Eds.; Colección de Estudios Económicos de La Caixa: Barcelona, Spain, 2005; pp. 92-93.

45. Mejías, F. Programas comunitarios de desarrollo rural. Aplicación e impacto en Extremadura. In Desarrollo Rural de Base Territorial: Extremadura; González, J., Ed.; MAPA and Consejería Desarrollo Rural Junta Extremadura: Badajoz, Spain, 2006; p. 214.

46. European Commission. Agenda 2000. For a Stronger and Wider Union; COM (97) 2000; Supplement 5/97; Publications Office of the European Communities: Luxembourg, 1997.

47. Hervieu, B. Agricultura y desarrollo rural: La convergencia necesaria. Leader II Mag. 1997, 15, 6-13.

48. European Commission. Financial Report of the European Union 2002; Office of Official Publications of the European Communities: Luxembourg, 2003.

49. García Grande, M.J. El último decenio: Aplicación y consecuencias de las reformas de la PAC. In Política Agraria Común: Balance y Perspectivas; García Delgado, J.L., García Grande, M.J., Eds.; Colección de Estudios Económicos de La Caixa: Barcelona, Spain, 2005; p. 62.

50. García Álvarez-Coque, J.M. La reforma de la PAC y el futuro de las ayudas agrarias. Revista Valenciana de Economía y Hacienda 2004, 11, 163-183.

51. Massot, A. La PAC, entre la Agenda 2000 y la Ronda del Milenio: ¿A la búsqueda de una política en defensa de la multifuncionalidad agraria? Revista Estudios Agro-sociales y Pequeros 2000, 188, 9-66.

52. Massot, A. La Política Agrícola Común frente a la Ronda del Milenio. En defensa de la multifuncionalidad agrarian. ICE 2000, 2651, 23-30.

53. Castillo Valero, J.S.; Ramos Real, E. El nuevo desarrollo rural y el futuro de la política rural en la Unión Europea. In Chequeo Médico de la PAC; García Álvarez-Coque, J.M., Gómez Limón, J.A., Eds.; MARM and Eumedia S.A.: Madrid, Spain, 2010; pp. 177-212.

54. European Commission: Communication to the Member States, Laying Down Guidelines for the Community Initiative for Rural Development (Leader +) (2000/C 139/05). Official Journal of the European Communities on May 18, 2000. Available online: https://eur-lex.europa.eu/legal-content/ES/TXT/PDF/?uri=CELEX: 32000Y0518(01)\&from=ES (accessed on 11 March 2019).

55. Ministerio de Agricultura, Pesca y Alimentación: Real Decreto 2/2002, de 11 de Enero, por el que se Regula la Aplicación de la Iniciativa Comunitaria “Leader Plus” y los Programas de Desarrollo Endógeno Incluidos en los Programas Operativos Integrados y en los Programas de Desarrollo Rural (PRODER). Boletín Oficial del Estado, n 11, 12 de enero de 2002. Available online: https://www.boe.es/boe/dias/2002/01/12/pdfs/A0151001523.pdf (accessed on 11 March 2019).

56. MEMO/03/236. Conclusions of Second European Conference on Rural Development in Salzburg. 2003. Available online: https://www.google.com.hk/url?sa=t\&rct=j\&q=\&esrc=s\&source=web\&cd=1\&ved= 2ahUKEwjnsN35ueriAhXZc94KHY-KDVsQFjAAegQIAxAC\&url=http\%3A\%2F\%2Feuropa.eu\%2Frapid\% 2Fpress-release_MEMO-03-236_en.pdf\&usg=AOvVaw1FmcYXHbxX08C7hhsKLbol (accessed on 2 January 2019).

57. Viladomiu, L.; Rosell, J. Análisis comparativo de los Programas de Desarrollo Rural 2007-2013: Niveles español y europeo. In Proceedings of the VII Reunión CIER, Coimbra, Portugal, 14-16 October 2008. 
58. Viladomiu, L.; Rosell, J. Los Programas de Desarrollo Rural (2007-2013) de la Unión Europea y sus enfoques alternativos. In Cultura, Inovação e Território. O Agroalimentar e o Rural; SPER: Lisbon, Portugal, 2009; pp. 51-61.

59. Compés, R. De la deconstrucción a la refundación: Elementos para un cambio de modelo de la reforma de la PAC 201. In Chequeo Médico de la PAC; García Álvarez-Coque, J.M., Gómez Limón, J.A., Eds.; MARM and Eumedia S.A.: Madrid, Spain, 2010; p. 145.

60. Foro IESA. Del Desarrollo Rural al Desarrollo Territorial. Reflexiones a Partir de la Experiencia Española; Ministerio de Medio Ambiente y Medio Rural y Marino, FEADER: Madrid, Spain, 2009.

61. Copus, A.; Shucksmith, M.; Dax, T.; Meredith, D. Cohesion Policy for rural areas after 2013. A rationale derived from EDORA project. Stud. Agric. Econ. 2011, 113, 121-132. [CrossRef]

62. FAO. Food and Agriculture Organization of the United Nations. The Future of Food and Agriculture. Trends and Challenges; FAO: Rome, Italy, 2017. Available online: http://www.fao.org/3/a-i6583e.pdf (accessed on 11 March 2019).

63. Hogan, P. La innovación y la sostenibilidad en el medio rural, prioridades de la nueva PAC. In Anuario de la Fundación de Estudios Rurales; Fundación Estudios Rurales: Madrid, Spain, 2018; pp. 6-8.

64. Yin, R. Case Study Research and Applications: Design and Methods; SAGE: Los Angeles, LA, USA, 2018.

65. Durán, M. El estudio de caso en investigación cualitativa. Revista de Administración 2012, 3, $121-134$. [CrossRef]

66. Jiménez, V.; Comet, C. Los estudios de casos como enfoque metodológico. ACADEMO Revista de Investigación en Ciencias Sociales y Humanidades 2016, 3, 1-11.

67. Yin, R. Qualitative Research from Start to Finish; The Guilford Press: New York, NY, USA, 2016.

68. Coller, X. Estudio de casos. In Colección de Cuadernos Metodológicos, 30th ed.; Centro de Investigaciones Sociológicas: Madrid, Spain, 2000; p. 56.

69. Centro de Estudios Caja España. Informe datos Económicos y Sociales Comarca de La Vera; Caja España de Inversiones: Salamanca/Soria, Spain, 2012.

70. Saraceno, E. Las ambigüedades de la política rural de la Unión Europea. Posibles escenarios de reforma. In Anuario de la Fundación de Estudios Rurales; Fundación Estudios Rurales: Madrid, Spain, 2018; pp. 50-59.

(C) 2019 by the authors. Licensee MDPI, Basel, Switzerland. This article is an open access article distributed under the terms and conditions of the Creative Commons Attribution (CC BY) license (http://creativecommons.org/licenses/by/4.0/). 